\title{
ANALISIS PEMBANGUNAN DESA BERBASIS PERENCANAAN DI DESA TANG KECAMATAN BOKAT KABUPATEN BUOL
}

\section{ANALYSIS OF PLANNING-BASED VILLAGE DEVELOPMENT IN TANG VILLAGE, BOKAT DISTRICT, BUOL REGENCY}

\author{
${ }^{1}$ Moh. Nasir Hasan Dg. Marumu, ${ }^{2}$ Ramlawati, ${ }^{3}$ Irawati Ahmad \\ Ekonomi Pembangunan, Sekolah Tinggi Ilmu Ekonomi Mujahidin \\ ${ }^{1}$ moh.nasirmarumu@stiemujahidin.ac.id \\ ${ }^{2}$ ramlawati@stiemujahidin.ac.id \\ ${ }^{3}$ hmad.irawati@gmail.com
}

\begin{abstract}
ABSTRAK
Pembangunan Desa bertujuan meningkatkan kesejahteraan masyarakat Desa dan kualitas hidup manusia serta penanggulangan kemiskinan melalui pemenuhan dasar, pembangunan sarana dan prasarana Desa, pengembangan potensi ekonomi lokal, serta pemanfaatan sumber daya alam dan lingkungan secara berkelanjutan. Desa Tang Kecamatan Bokat Kabupaten Buol sebagai salah satu unit pemerintah yang berada dibawa pemerintahan wajib menyusun dokumen perencanaan pembangunan yaitu rencana pembangunan jangka menengah Desa (RPJM Desa) dan rencana pembangunan tahunan Desa atau yang disebut rencana kerja Pemerintah Desa (RKP Desa) untuk pembangunan desa. Mengingat ini merupakan tanggung jawab harus dilaksanakan oleh Pemerintah Desa Tang. Keterlibatan atau partisipasi dari masyarakat menjadi syarat mutlak dalam proses penyusunan rencana kerja Pemerintah Desa (RKP Desa). Keterlibatan ini dimaksudkan agar masyarakat bisa memberikan kontribusi positif terhadap perencanaan pembangunan Desa. Tujuan penelitian yang akan dianalisis adalah untuk mengetahui pembangunan Desa berbasis perencanaan di Desa Tang Kecamatan Bokat Kabupaten Buol. Jenis penelitian ini menggunakan metode deskriptifanalisis dengan pendekatan kualitatif, agar studi kasus yang didapatkan dalam penelitian ini bisa dibandingkan dengan pengalaman peneliti lain. Metode penelitian yang digunakan adalah metode deskriptif analisis dengan pendekatan kualitatif dengan menggunakan tabel frekuensi kemudian diinterprestasikan berdasarkan kategori kategori sesuai dengan data yang diperoleh dilapangan (data primer) yang kemudian secara deskriptif diukur dengan menggunakan Skala Likert. Kesimpulan dalam penelitian ini adalah bahwa pembangunan Desa berbasis perencanaan di Desa Tang Kecamatan Bokat kabupaten Buol mencapai kategori Sangat Baik
\end{abstract}

Kata Kunci : Analisis Pembangunan, desa, perencanaan

\begin{abstract}
Village development aims to improve the welfare of the village community and the quality of human life as well as poverty alleviation through basic fulfillment, development of village facilities and infrastructure, development of local economic potential, and sustainable use of natural resources and the environment. Tang Village, Bokat District, Buol Regency as one of the government units under the government is required to compile a development planning document, namely the Village Medium-Term Development Plan (RPJM Desa) and the Village Annual Development Plan or the so-called Village Government Work Plan (RKP Desa) for village development. Considering this is a responsibility, it must be carried out by the Tang Village Government. The involvement or participation of the community is an absolute
\end{abstract}


requirement in the process of preparing the Village Government work plan (RKP Desa). This involvement is intended so that the community can make a positive contribution to village development planning. The research aims to be analyzed to determine the planning-based village development in Tang Village, Bokat District, Buol Regency. This type of research uses a descriptive analysis method with a qualitative approach so that the case studies obtained in this study can be compared with the experiences of other researchers. The research method used is the descriptive analysis method with a qualitative approach using a frequency table and then interpreted based on categories according to the data obtained in the field (primary data) which is then descriptively measured using a Likert Scale. The conclusion in this study is that planning-based village development in Tang Village, Bokat District, Buol Regency reaches the Very Good category.

Keywords: Development Analysis, village, planning

\section{PENDAHULUAN}

Desa Tang Kecamatan Bokat Kabupaten Buol sebagai salah satu unit pemerintah yang berada dibawa pemerintahan wajib menyusun dokumen perencanaan pembangunan yaitu rencana pembangunan jangka menengah Desa (RPJM Desa) dan rencana pembangunan tahunan Desa atau yang disebut rencana kerja Pemerintah Desa (RKP Desa) untuk pembangunan Desa. Mengingat ini merupakan tanggung jawab harus dilaksanakan oleh Pemerintah Desa Tang. Keterlibatan atau partisipasi dari masyarakat menjadi syarat mutlak dalam proses penyusunan rencana kerja Pemerintah Desa (RKP Desa). Keterlibatan ini dimaksudkan agar masyarakat bisa memberikan kontribusi positif terhadap perencanaan pembangunan Desa.

Tujuan penelitian yang akan dianalisis adalah untuk mengetahui pembangunan Desa berbasis perencanaan di Desa Tang Kecamatan Bokat Kabupaten Buol.

Pembangunan

Pembangunan di Desa dapat menyentuh seluruh lapisan masyarakat maka harus di terapkan prinsip-prinsip pembangunan, sasaran pembangunan dan ruang lingkup pembangunannya, berikut menjelaskan mengenai 3 unsur tersebut menurut Adisasmita (2006:18-20) :
1. Pembangunan pedesaan seharusnya menerapkan prinsip transparasi (keterbukaan, partisipatif, dapat dinikmati masyarakat, dapat dipertanggung jawabkan akuintabilitas) dan berkelanjutan (sustainabtle).

2. Sasaran pembangunan pedesaan yaitu untuk terciptanya peningkatan keterampilan dalam berproduksi dan pengembangan lapangan kerja dan lapangan usaha produktif, peningkatan prakarsa dan partisipasi masyarakat serta perkuatan kelembagaan.

3. Pembangunan pedesaan yang mempunyai ruang lingkup pembangunan sarana dan prasarana pedesaan (meliputi pengairan, jaringan jalan, lingkungan, pemukiman dan lainnya), pemberdayaan masyarakat, pengelolaan sumber daya alam (SDA) dan sumber daya manusia (SDM), penciptaan lapangan kerja, kesempatan berusaha, peningkatan pendapatan (khususnya terhadap kawasan-kawasan miskin) dan penataan keterkaitan antar kawasan pedesaan dan kawasan perkotaan (interurral-urban relationship).

Pembangunan Desa

Menurut Widjaja (2003:45) dalam bukunya "Otonomi Desa" menyatakan bahwa "Desa adalah kesatuan masyarakat hukum yang mempunyai susunan asli 
berdasarkan hak asal usul yang bersifat istimewa, landasan pemikiran dalam mengenai Desa adalah keanekaragaman, partisipasi, otonomi asli, demokratisasi dan pemberdayaan masyarakat. Desa sebagai suatu bagian dari sistem Pemerintahan Negara Kesatuan Republik Indonesia yang diakui otonominya dan Kepala Desa melalui pemerintah Desa dapat diberikan penugasan pendelegasian dari pemerintahan ataupun pemerintahan daerah untuk melaksanakan urusan pemerintah tertentu.

Proses pembangun Desa merupakan mekanisme dari keinginan masyarakat yang di padukan dengan masyarakat. Perpaduan tersebut menentukan keberhasilan pembangunan seperti yang di kemukakan oleh Ahmadi (2001 : 222) mekanisme pembangunan Desa adalah merupakan perpaduan yang serasi antara kegiatan partisipasi masyarakat dalam pihak dan kegiatan pemerintah di satu pihak.

Suparno (2001 : 46) menegaskan bahwa pembangunan Desa di lakukan dalam rangka imbang yang sewajarnya antara pemerintah dengan masyarakat. Kewajiban pemerintah adalah menyediakan prasaran-prasarana, sedangkan selebihnya di sandarkan kepada kemampuan masyarakat itu sendiri.

\section{Perencanaan Pembangunan Desa}

Proses perencanaan sesuai pendapat A.M. Willams(1996) yang diikuti oleh Affifuddin (2012),proses dari perencanaan meliputi: menentukan atau menetapkan dengan jelas maksud dan tujuan, menentukan alternatif, mengatur sumbersumber yang diperlukan, menentukan organisasi metode dan prosedur, menentukan atau menetapkan rencana itu sendiri.

Menurut Kunarjo (2002) jenis-jenis perencanaaan dapat disusun berdasarkan empat kriteria, yaitu : dilihat dari jangka waktu, di lihat dari ruanglingkup, dilihat dari tingkat keluwesan perencanaan, dilihat dari arus perencanaan.
Afifuddin (2012:94) menjelaskan bahwa perencanaan merupakan sistem dalam melaksanakan dan mengevaluasi setiap kegiatan karena pada dasarnya perencanaan mempunyai beberapa fungsi, yaitu:

1. Dikaitkan dengan pelaksanaan kegiatan oprasional, rencana merupakan alat efisiensi dan efektifitas untuk menghindari pemborosan berkat keterarahan untuk mencapai tujuan.

2. Dengan rencana yang matang, dilakukan perkiraan keadaan mengenai hal-hal dan prospek perkembangan masa depan yang pada gilirannya dapat mengurangi ketidak pastian yang akan dihadapi.

3. Perencanaan memberikan kesempatan untuk memilih berbagai alternatif tentang cara yanag diduga merupakan cara terbaik, setelah melalui pengkajian mendalam, dapat memberi petunjuk tentang ciri ciri setiap alternatif, baik sifatnya positif maupun negatif.

4. Dengan adanya rencana, tergambar pula jenis dan bentuk satuan satuan penyelanggara semua kegiatan yang sifatnya berlanjut dan oleh karenanya melembaga.

5. Rencana dapat dijadikan sebagai dasar utama untuk penjabaran program kerja secara sistematik. Implikasi pembiayaan pun dapat terlihat dengan jelas dalam suatu rencana.

6. Dengan rencana yang jelas, sarana dan prasarana kerja yang mutlak diperlukan dapat disediakan sesuai dengan kebutuhan yang sebenarnya.

Proses perencanaan pembangunan Desa yang harus dilihat dan dipahami bahwa perencanaan pembangunan Desa merupakan suatu panduan atau model penggalian potensi dan gagasan pembangunan Desa yang menitik beratkan pada peran serta masyarakat dalam keseluruhan proses pembangunan (Supeno, 2011:32).

\section{METODE}


Jenis penelitian ini menggunakan metode deskriptifanalisis dengan pendekatan kualitatif, agar studi kasus yang didapatkan dalam penelitian ini bisa dibandingkan dengan pengalaman peneliti lain. Dalam penelitian ini peneliti melakukan observasi dengan pihak pemangku kepentingan yaitu pemerintah Desa, Lembaga Pemberdayaan Masyarakat (LPM), Badan Permusyawaratan Desa (BPD) dan sebagian masyarakat Desa Tang untuk mendapatkan informasi dan dukumen- dukumen yang berkaitan dengan penelitian yang dilakukan oleh peneliti.

Penelitian dilaksanakan di Desa Tang Kecamatan Bokat Kabupaten Buol dengan waktu penelitian selama enam bulan yang akan dimulai bulan Juni sampai dengan Desember 2020. Dalam penelitian ini populasi yang digunakan untuk pengambilan data adalah Pemerintah Desa, Lembaga Pemberdayaan Masyarakat (LPM), Badan Permusyawaratan Desa BPD) dan sebagian masyarakat Desa Tang. Penulis menggunakan teknik Purposive Sampling untuk menentukan jumlah sampel dalam penelitian ini dengan hasil sampel sebanyak 30 orang termasuk kepala desa dan perangkatnya beserta masyarakat desa.

$\begin{array}{cccr}\text { Data } & \text { dalam } & \text { penelitian } & \text { ini } \\ \text { dikumpulkan } & \text { dengan } & 3 & \text { cara yaitu }\end{array}$ observasi, wawancaradan kuisioner. metode deskriptif analisis dengan pendekatan kualitatif dengan menggunakan tabel frekuensi kemudian diinterprestasikan berdasarkan kategori kategori sesuai dengan data yang diperoleh dilapangan (data primer) yang kemudian secara deskriptif diukur dengan menggunakan Skala Likert.

\section{HASIL DAN PEMBAHASAN}

Desa dengan ama Tang diambil dari terumbukarang yang berbentuk seperti Tang, yaitu karang yang bertumpuktumpuk jika diartikan dalam Bahasa Buol
(Gitatangan), maka salah satu tokoh Legenda masyarakat pada saat itu juga namanya PITANG menyebutnya Tang.

Tokoh Pitang menurut cerita dan kepercayaan secara turun-temurun oleh masyarakat Tang adalah sosok manusia yang diasingkan oleh penduduk Desa Tang, disalah satu tempat yang terpencil yang letaknya di muara sungai di dusun satu Desa Tang, dikarenakan memiliki penyakit wabah yang dianggap menular jika diartikan dengan Bahasa Buol penyakit (Magugu), disanalah Pitang dibuatkan gubuk kecil dan hidup dengan seorang diri, keluarga Pitang kadang masih menyempatkan diri menengok dan mengantarkan makanan hingga pada satu ketika sosok Pitang tiba-tiba menghilang dan kabarnya pun tidak terdengar oleh keluarga. Setelah sekian lamanya hidup terasingkan dan dianggap hilang, sosok Pitang tiba-tiba kembali muncul di tengah keluarga dan penduduk, yang sudah berubah wujud menjelma menjadi sosok yang misterius kemudian menyampaikan pesan jika sosoknya telah menikah dengan makhluk halus ditempat perasingannya, dalam pesannya itu jika ada penduduk yang mencari ikan dimuara sungai tersebut, dan dia bersiul dan terdengar suara denguan jika diartikan dalam Bahasa Buol (Mogimuk) maka lekas menjauh dari tempat itu, dikarenakan istri Pitang sedang berada disampingnya, dan istri Pitang dikenal sangat jahat sebagai penghuni dari muara sungai kecil tempat Pitang diasingkan, namun jika salah seorang penduduk mencari tangkapan ikan dan keberadaannya disenangi sosok Pitang maka hasil tangkapannya menjadi banyak, dan sampai saat ini cerita legenda Pitang bersama istrinya tersebut masih melekat dikalangan masyarakat.

Wilayah Desa Tang dengan luas wilayah \pm 9.100 ha terdiri dari areal pertanian, areal perkebunan masyarakat, 
areal perawahan, areal pemukiman, areal dan lain-lain. Secara geografis Desa Tang merupakan salah satu Desa dikecamatan Bokat. Dan letak wilayah Desa Tang berada diposisi kordinat $121^{\circ} \mathrm{s} / \mathrm{d} 121^{\circ} \mathrm{BT}$ (Bujur Timur) $0^{\circ}$ s/d $1^{\circ}$ LU (Lintang Utara) dan berada diketinggian $3 \mathrm{Mdpl}$ dengan kemiringan lahan sebagai berikut : dataran $25 \%$, perbukitan $25 \%$, pegunungan $50 \%$.

Dari hasil olahan data pada penelitian ini menunjukan bahwa pembangunan Desa berbasis perencanaan di Desa Tang Kecamatan Bokat kabupaten Buol mencapai kategori Sangat Baik, dengan skor rata-rata $6,53.67$ atau $83 \%$. Secara sederhana dapat diuraikan sebagai berikut :

1. Menetapkan tugas dan tujuan perencanaan mencapai nilai rata-rata 970 atau $80 \%$ responden menyatakan Sangat Setuju. Artinya pembangunan berbasis perencanaan sudah dilaksanakan sesuai ketentuan penetapan tujuan pembangunan.

2. Mengobservasi dan menganalisis mencapai nilai rata-rata 10,73 atau $89 \%$ responden menyatakan Sangat Setuju. Artinya hasil pada tahap menganalisis lebih baik dalam penyusunan pembangunan berbasis perencanaan.

3. Identifikasi peluang dan hambatan perencanaan mencapai nilai rata-rata 980 atau $81 \%$ responden menyatakan Sangat Setuju. Artinya segala bentuk kendala-kendala sudah dipersiapkan secara matang dalam rencana pembangunan.

\section{KESIMPULAN DAN SARAN}

Kesimpulan dalam penelitian ini adalah bahwa pembangunan Desa berbasis perencanaan di Desa Tang Kecamatan Bokat kabupaten Buol mencapai kategori Sangat Baik.

Dalam kesempatan ini penulis menyampaikan saran kepada pemerintah
Desa Tang agar terus menjaga hubungan Kerjasama antara Pemdes dan Masyarakat, Pemdes harus menjadikan masyarakat sebagai pelaku dalam pembangunan dan juga dapat lebih mengembangkan potensi yang ada di Desa.

\section{UCAPAN TERIMAKASIH}

Kami mengucapkan terimakasih kepada STIE Mujahidin Tolitoli yang telah memperikan ruang dan kesempatan kepada kami untuk melaksanakan penelitian ini. Tak lupa pula kami ucapkan terimakasih kepada Fakultas Ekonomi Universitas Indonesia Timur yang telah memberikan kami sarana untuk mempublikasikan hasil penelitian kami.

\section{DAFTAR PUSTAKA}

Abu Ahmadi. 2001. Ilmu Pendidikan.Jakarta :Rineka Cipta

Adisasmita, $\quad$ Rahardjo. 2006. Pembangunan Pedesaan Dan Perkotaan.Yogyakarta : Graha Ilmu

Afifuddin. 2012. PengantarAdministrasi Pembangunan. Bandung : Alfabetha.

Rabie, R., \& Elliyana, E. (2019). Human capital and economic growth in Indonesia. Journal of Contemporary Economic Studies, 4(01), 169-176.

Suparno, 2001. Membangun Kompetensi Belajar. Jakarta : Direktorat Jendral Pendidikan Tinggi, Departemen Pendidikan Nasional.

Supeno Wahyudin. 2011. Perencanaan Desa Terpadu Edisi Revisi, Read : Banda Aceh.

Widjaja, HAW. 2003. Otonomi Desa. Jakarta : Raja GrafindoPersada. 